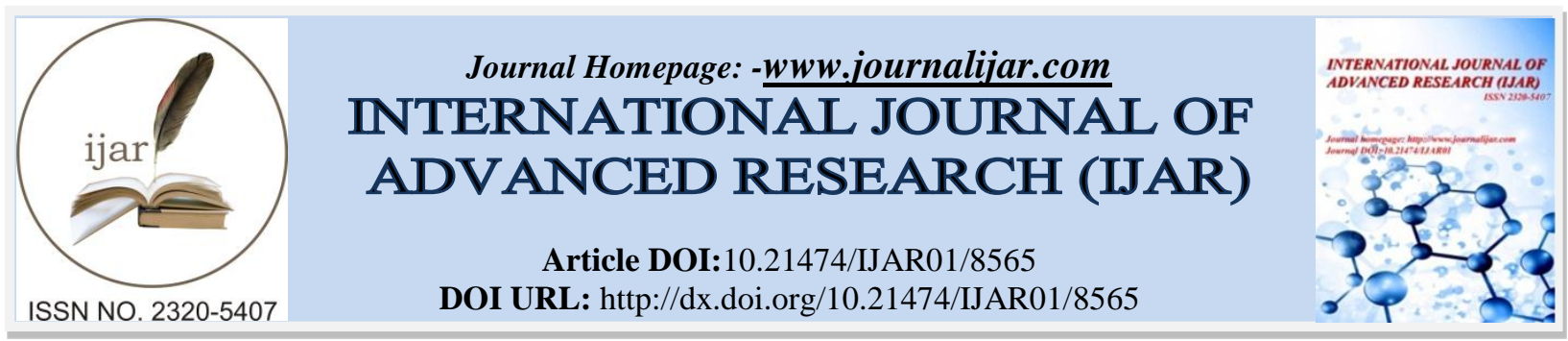

RESEARCH ARTICLE

\title{
SERUM IGF-1\& URIC ACID IN PATIENTS WITH PARKINSON'S DISEASE AND PARKINSON PLUS SYNDROME.
}

\section{Missamma Mulagala ${ }^{1}$, Ritu Shree ${ }^{2}$, Gunjan Goyal ${ }^{3}$, Manoj K Goyal ${ }^{2}$, Sahil Mehta ${ }^{2}$, Manish Modi ${ }^{2}$, B R Mittal $^{4}$ and Bikash Medhi ${ }^{1}$.}

1. MD, Department of Pharmacology, Post Graduate Institute of Medical Education and Research, Chandigarh, India.

2. DM, Department of Neurology, Post Graduate Institute of Medical Education and Research, Chandigarh, India.

3. M Phil, Department of Medical Parasitology, Post Graduate Institute of Medical Education and Research, Chandigarh, India.

4. MD, DNB, Department of Nuclear Medicine, Post Graduate Institute of Medical Education and Research, Chandigarh, India.

\section{Manuscript Info}

\section{Manuscript History}

Received: 14 December 2018

Final Accepted: 16 January 2019

Published: February 2019

Key words:-

Parkinson's disease; Parkinson plus syndrome; IGF-1; Uric acid.

\section{Abstract}

Background: Development of biomarkers in Parkinson's disease (PD) and Parkinson Plus Syndrome (PPS) is still at an elementary stage. Recent studies have yielded conflicting results on the role of insulin like growth factor (IGF-1) \& uric acid as biomarkers in PD. We evaluated the role of serum IGF-1 and uric acid as diagnostic and prognostic markers in PD.

Objectives:

1. To evaluate the role of serum IGF-1 \& uric acid as biomarkers for differentiating PD from Parkinson plus syndrome and healthy controls.

2. To study the correlation of levels of serum IGF-1\& uric acid with duration and severity of illness in PD.

Methods: Current study included 99 patients with Parkinsonism and 68 healthy volunteers. Patients were diagnosed as PD, multisystem atrophy (MSA), progressive supranuclear palsy (PSP), and corticobasal ganglionic degeneration (CBGD) as per standard criteria. Written informed consent was obtained from all patients included in the study. All patients underwent complete neurological examination, MMSE (Mini Mental State Examination), UPDRS (Unified Parkinson Disease Rating Scale) and MRI brain. Serum IGF-1 was measured by DRG IGF-1 600 ELISA kit (Catalogue No: 18K116: DRG Instruments Gm $\mathrm{BH}$, Germany). Serum uric acid was measured by INFINITE Uric acid assay kit (Accurex Biomedical PVT.LTD., Mumbai, INDIA).

Results:Serum IGF-1 levels were significantly elevated $(p<0.01)$ \& uric acid levels were significantly decreased $(\mathrm{p}<0.01)$ in PD patients compared to controls, but the difference in serum IGF-1 \& uric acid levels in various Parkinsonism groups (PD, YOPD, PSP, MSA, CBGD) were not significant.

Conclusion: Serum IGF-1 levels were increased \& uric acid decreased in PD. Further studies employing higher sample size and longitudinal 
measurement of serum IGF-1 and uric acid will help in delineating their role as biomarkers in PD.

Copy Right, IJAR, 2019,. All rights reserved.

\section{Introduction:-}

Parkinson's disease is the second most common neurodegenerative disorder next to Alzheimer's disease that affects nearly $2 \%$ of population aged more than 60 years. Pathologically, PD is characterized by abundant depletion of dopaminergic neurons in substantia nigra that results in clinical features of resting tremor, rigidity, bradykinesia and postural disturbances.[1-3] However, despite decades of research, pathogenesis of nigral neuronal loss continues to be elusive. Recent data suggests that oxidative stress plays an important role in destruction of dopaminergic neurons in PD and insulin like growth factor (IGF-1), a 70 amino acid polypeptide has shown to be protective against oxidative damage to dopaminergic neurons in animal models of PD.[4]

Although several studies have shown serum IGF-1 levels to be higher and serum uric acid is lower in PD patients compared to healthy controls, the results of these studies are not consistent.[5-9]

Biomarker is defined as any feature which can be used to diagnose or measure or prognosticate a disease process or determine its response to treatment. Various biomarkers have been proposed in PD including $\alpha$ - synuclein, DJ-1, Apo A1, pentraxin 3, serum melatonin, lymphocyte vitamin C, but none of these were clearly found to be associated with the development of $\mathrm{PD}[10]$ and till date we don't have a biomarker which is clearly implicated in diagnosis of $\mathrm{PD}$ and its differentiation from Parkinson plus syndromes.[11]

IGF-1 is a potential biomarker for PD which plays a vital role in cell differentiation and survival of neurons in nervous system. It is found in high concentrations in substantia nigra and is known to increase survival of dopaminergic neurons as well as protect them from dopamine induced oxidative damage in vitro.[12] However, though serum levels of IGF-1 were found to be elevated compared to controls in some studies, other studies have not reported such an association.[13-14] In addition, relationship of levels of serum IGF-1 with duration and severity of PD and its role in differentiation of PD from Parkinson plus syndrome is still to be elucidated.

Uric acid is a major antioxidant and various studies have demonstrated that low levels of serum uric acid confer increased risk of developing PD in later part of life. Uric acid has free radical scavenging properties (scavenger of peroxyl and hydroxyl radicals) and has the ability of metal complexing capabilities, all together uric acid bind with iron and copper and reduce their ability to produce reactive oxygen species (ROS). [15-16]

Various studies have concluded that low serum uric acid has increased risk of developing PD in elderly and uric acid can serve as a prognostic biomarker in identifying PD disease progression.[17]

Thus, we conducted this study to evaluate the role of serum IGF-1 and uric acid in differentiating PD from healthy controls and other Parkinson plus syndromes. We also aimed to observe the relationship of levels of serum IGF-1 and uric acid with duration and severity of PD.

\section{Aims And Objectives:-}

1. To evaluate the role of serum IGF-1 \& uric acid as biomarkers for differentiating PD from Parkinson plus syndrome and healthy controls.

2. To study the correlation of levels of serum IGF-1 and uric acid with duration and severity of illness in PD.

\section{Patients And Methods:-}

Current study was conducted by department of Pharmacology in collaboration with department of Neurology at a tertiary care teaching hospital and referral institute in North India from July 2015 to December 2016. The present study was conducted in accordance with the Declaration of Helsinki, applicable regulatory guidelines and in adherence to the study protocol. The present study was approved by Institutional Ethics Committee (INT/IEC/2015/822) and was registered in CTRI (REF/2015/12/010338). Written informed consent was obtained from all patients included in the study. During this period, we identified 101 patients who fulfilled diagnostic criteria for Parkinsonism. Two patients were excluded as one had drug induced Parkinsonism and other had vascular 
Parkinsonism. The study group consisted of 99 patients, 68 age and sex matched healthy volunteers as controls. After enrolment into the study, all patients underwent detailed history, clinical examination, neurological examination, MMSE, and investigations as per predesigned proforma. Further division of Parkinsonism patients into Parkinson's disease (PD), progressive supranuclear palsy (PSP), multisystem atrophy (MSA) and corticobasal ganglionic degeneration (CBGD) was made as per standard criteria.[18-21] All the patients underwent UPDRS (Unified Parkinson Disease Rating Scale).[22] MRI brain was done in all the patients. All patients received treatment as per the standard treatment guidelines. They were followed up regularly in movement disorder clinic of our institute. Hoehn and Yahr (H \& Y) staging [23] was used to assess the severity of disease. Patients with PD were further divided into young onset PD (YOPD) $(n=10)$ if disease onset was below 40 years of age. The inclusion and exclusion criteria for the study group are given below.

\section{Inclusion criteria}

1. Patients aged more than 18 years

2. Diagnosis of PD $(n=77)$ or Parkinson plus syndrome (PPS) [PSP $(n=14)$, MSA $(N=7)$, CBGD $(n=2)$ ]

\section{Exclusion criteria}

1. PD patients with severe comorbidities

2. PD patients with acromegaly / gigantism

3. Patients with protein malnutrition

4. Drug induced/ vascular Parkinsonism

5. Control subjects with the following comorbidities

1. Neurological disorders

2. Psychiatric disorders

3. Dementia

4. Diabetes mellitus

5. Thyroid disease

6. Obesity / BMI $\geq 30$

\section{Estimation of IGF-1 by ELISA and Uric acid by Spectrophotometry}

Venous blood samples were collected in clot activated vacutainers from patients and controls and centrifuged immediately to obtain serum. Serum samples were stored at $-20^{\circ} \mathrm{C}$ until the analysis of serum IGF-1 and uric acid. Serum IGF-1 was measured by DRG IGF-1 600 ELISA kit. (Catalogue No. 18K116, DRG Instruments Gm, BH Germany). Serum Uric acid was measured by INFINITE Uric acid assay kit (Accurex Biomedical PVT.LTD.,Mumbai, INDIA) using Spectrophotometry.

\section{Statistical Analysis:-}

Data was analysed using IBM-SPSS version 22. Data was expressed as mean and standard deviation. One way Anova with Bonferroni correction was used to compare continuous variables between multiple groups. The correlation of serum IGF-1 and uric acid levels with various clinical parameters were assessed using Pearson's correlation coefficient. Discrete variables were compared using Chi square test. Two tailed p value <0.05 was considered statistically significant.

\section{Results:-}

\section{Demographic profile:}

Present study included 99 patients with Parkinsonism. The results were compared with 68 age and sex matched healthy volunteers as controls. The demographic profile of the study group is provided in table 1.

\section{Serum levels of IGF-1 between various groups:}

The mean $( \pm \mathrm{SD})$ serum levels of IGF-1 among various groups were given in table 2. On analysis, serum levels of IGF-1 were found to be significantly elevated $(\mathrm{p}<0.001)$ in PD patients compared to controls. The difference in levels of serum IGF-1 between various Parkinsonism groups (PD, YOPD, PSP, MSA, CBGD) was not significant $(\mathrm{p}=0.622)$. Similarly, there was no significant difference in levels of serum IGF-1 when patients with different Parkinson plus syndromes were compared with controls. 


\section{Serum uric acid between various groups:}

The mean $( \pm \mathrm{SD})$ serum uric acid among various groups were given in table 2 . On analysis, serum uric acid was significantly decreased $(\mathrm{p}<0.001)$ in PD patients compared to controls. The difference in serum uric acid between various Parkinsonism groups (PD, YOPD, PSP, MSA, CBGD) was not significant ( $\mathrm{p}=0.173$ ). Similarly, there was no significant difference in serum uric acid between Parkinson Plus Syndrome and controls.

Comparison of Serum IGF-1 and Uric acid between total patients versus controls and PD versus PPS given in table 3.

Correlation between levels of serum IGF-1; uric acid and other disease related parameters in PD patients:

In current study, we tried to determine if various disease related factors (age of patient, age at onset of disease, duration of illness, total and motor UPDRS score) can correlate with serum IGF-1 and uric acid levels or not . On analysis, no significant correlation was observed between any of the above mentioned factors and levels of serum IGF-1 as indicated by Spearman rho and Pearson correlation. Significant inverse correlation of age of onset with serum uric acid levels $(r=-0.206, p=0.04)$ was observed whereas no significant correlation of serum uric acid was observed with age of patient, duration of illness, total and motor UPDRS score as indicated by Spearman rho and Pearson correlation (Table 4).

We further correlated levels of serum IGF-1 with severity of PD as determined by Hoehn and Yahr staging. Levels of serum IGF-1 were higher in patients with stage 5 disease $(504 \mathrm{ng} / \mathrm{ml})$ and stage 3 disease $(442.6 \pm 80.45 \mathrm{ng} / \mathrm{ml})$ compared to stage $2(357.43 \pm 130.53 \mathrm{ng} / \mathrm{ml})$ and stage $1(338.64 \pm 58.95 \mathrm{ng} / \mathrm{ml})$ disease. Serum IGF-1 Levels in stage 4 disease were $235.5 \pm 24.1 \mathrm{ng} / \mathrm{ml}$. However, on analysis, the difference among various groups was statistically insignificant.

\section{Sensitivity and specificity of serum IGF-1 and uric acid levels for diagnosis of PD or Parkinson plus} syndromes compared to controls:

To achieve above mentioned motif, we calculated area under the ROC. On analysis, it was found that serum IGF-1 levels of $300 \mathrm{ng} / \mathrm{ml}$ were $68 \%$ sensitive and $67 \%$ specific for differentiating PD or Parkinson plus syndrome from healthy controls. Similarly, serum IGF-1 levels of $300 \mathrm{ng} / \mathrm{ml}$ were $69 \%$ sensitive and $64 \%$ specific for differentiating PD patients from healthy controls. Serum uric acid levels of 5.98 were $66 \%$ sensitive and $65 \%$ specific in diagnosis of PD and for differentiation of PD from controls.

\section{Discussion:-}

Current study included 99 patients with PD ( $\mathrm{n}=77)$ and Parkinson plus syndromes $(\mathrm{n}=22)$. The demographic profile of patients was in accordance with previous studies and in general agreement with reported frequencies of PD and various Parkinson plus syndromes. In current study, levels of serum IGF-1 were found to be significantly highly elevated in patients with PD compared to healthy controls. These observations are in agreement with previous studies. Numao et al [9] conducted a case controlled study on 79 patients of early PD and 52 controls. They demonstrated high levels of serum IGF-1 in PD patients compared with controls. A meta-analysis by Li et al [24](166 PD patients and 323 healthy controls) demonstrated high levels of serum IGF-1 in PD patients compared with controls. Godau et al [7] conducted a study on 139 healthy controls and 15 PD patients found significant high serum IGF-1 in PD ( $\mathrm{P}=0.004)$. This study observed inverse correlation of levels of serum IGF-1 with UPDRS motor score.

The current study had demonstrated low serum uric acid levels in patients with PD compared with healthy controls. These observations will strengthen the results of previous studies, where in patients with decreased serum uric acid levels has high propensity of developing PD in later part of life.[15-17] These studies plus results of our study suggest that levels of serum IGF-1 and uric acid may serve as diagnostic biomarkers for PD. Our study did not find any correlation of disease severity with levels of serum IGF-1 as measured by UPDRS motor score and Hoehn and Yahr staging. Levels of serum IGF-1 were higher in patients with higher stage of PD as determined by Hoehn and Yahr stage, though the difference was not significant. This may be related to relatively small number of PD patients in stage 1, 4 and 5. Our study did not find any correlation of serum uric acid levels with UPDRS motor score and Hoehn and Yahr staging. No correlation of levels of serum IGF-1 with duration of illness and age at onset was observed in current study. Significant inverse correlation of age of onset with serum uric acid levels $(r=-0.206$, $\mathrm{p}=0.04$ ) was observed whereas no significant correlation of serum uric acid was observed with age of patient, duration of illness, total and motor UPDRS score. This may be related to the fact that duration of illness was roughly similar in most of the patients in current study. 
We observed no significant difference of serum IGF-1 levels between PD and PPS groups. Thus, though serum IGF1 levels may help in differentiating PD patients from controls, they are of limited utility in differentiating PD patients from patients with Parkinson plus syndrome. However, these results need to be replicated in studies with much higher sample size as numbers of patients with various Parkinson plus syndromes were relatively small in current cohort.

To conclude results of our study confirm that serum IGF-1 levels are indeed elevated in PD patients compared to healthy controls. Further studies employing higher sample size and based on measurement of serum IGF-1 levels will further help in delineating its role as as a biomarker in PD.

\section{Acknowledgement:-}

Dr. Ajay Prakash, Assistant Professor, Department of Phramacology, PGIMER, ChandigarhAll my patients, medical staff of our hospital

\section{Conflict of interest:}

The authors declared no conflict of interest

Source of funding:

Post Graduate Institute of Medical Education and Research (PGIMER), Chandigarh

Table 1:-Demographic profile of study groups

\begin{tabular}{|c|c|c|c|c|c|c|c|}
\hline & $\begin{array}{c}\text { IPD } \\
(n=66)\end{array}$ & $\begin{array}{l}\text { YOPD } \\
(n=10)\end{array}$ & $\begin{array}{c}\text { PSP } \\
(n=14)\end{array}$ & $\begin{array}{l}\text { MSA } \\
(n=7)\end{array}$ & $\begin{array}{c}\text { CBGD } \\
(n=2)\end{array}$ & $\begin{array}{c}\text { All } \\
\text { patients } \\
(n=99)\end{array}$ & $\begin{array}{c}\text { Controls } \\
(n=68)\end{array}$ \\
\hline Age & $60.68 \pm 9.89$ & $35.2 \pm 7.99$ & $63.50 \pm 6.75$ & $63.14 \pm 10.68$ & $63 \pm 4.24$ & $\begin{array}{l}58.72 \pm \\
12.16\end{array}$ & $58.95 \pm 6.18$ \\
\hline Age at onset & $56.57 \pm 9.84$ & $30.79 \pm 8.31$ & $60.46 \pm 6.57$ & $60.42 \pm 9.10$ & $62 \pm 4.24$ & $\begin{array}{l}54.9 \pm \\
12.26 \\
\end{array}$ & ---/--- \\
\hline $\begin{array}{l}\text { Male: } \\
\text { Female } \\
\end{array}$ & 54: 13 & $7: 3$ & $4: 3$ & $11: 3$ & 1: 1 & $77: 22$ & $41: 27$ \\
\hline $\begin{array}{l}\text { Duration of } \\
\text { illness }\end{array}$ & $4.10 \pm 4.09$ & $5.15 \pm 2.90$ & $3.10 \pm 1.97$ & $3.42 \pm 2.02$ & $1.5 \pm 0.7$ & $\begin{array}{l}3.93 \pm \\
3.59\end{array}$ & ---/--- \\
\hline \begin{tabular}{|l|} 
UPDRS \\
Motor score \\
\end{tabular} & $37.37 \pm 14.99$ & $38.5 \pm 23.39$ & $42.35 \pm 18.46$ & $47 \pm 23.02$ & $55 \pm 35.35$ & $\begin{array}{l}39.23 \pm \\
17.40\end{array}$ & ---/--- \\
\hline \begin{tabular}{|l|} 
UPDRS \\
Total score \\
\end{tabular} & $58.72 \pm 23.88$ & $55.9 \pm 41.07$ & $75.5 \pm 31.14$ & $84.71 \pm 37.1$ & $86.5 \pm 53.03$ & $\begin{array}{l}63.21 \pm \\
29.32\end{array}$ & ---/--- \\
\hline \multicolumn{8}{|c|}{ Hoehn \&Yahr Stage } \\
\hline \begin{tabular}{|l|} 
Stage 1 \\
\end{tabular} & $3(45.4 \%)$ & $2(0.2 \%)$ & 0 & 0 & 0 & $5(5.05 \%)$ & --- \\
\hline \begin{tabular}{|l|} 
Stage 2 \\
\end{tabular} & $48(72.7 \%)$ & $7(0.7 \%)$ & $1(7.1 \%)$ & $2(28.6 \%)$ & $1(50 \%)$ & $59(59.6)$ & --- \\
\hline Stage 3 & $12(18.2 \%)$ & 0 & $9(64.3 \%)$ & $1(14.3 \%)$ & 0 & $\begin{array}{l}22 \\
(22.2 \%)\end{array}$ & $\begin{array}{ll}-- \\
\end{array}$ \\
\hline Stage 4 & $2(3.03 \%)$ & $1(0.1 \%)$ & $2(14.3 \%)$ & $1(14.3 \%)$ & $1(50 \%)$ & $7(7.1 \%)$ & --- \\
\hline Stage 5 & $1(1.5 \%)$ & 0 & $2(14.3 \%)$ & $3(42.8 \%)$ & 0 & $6(6.1 \%)$ & --- \\
\hline
\end{tabular}

IPD: Idiopathic Parkinson's disease; YOPD: Young onset Parkinson disease; PSP: Progressive supranuclear palsy; MSA: Multi system atrophy; CBGD: Corticobasal ganglionic degeneration; UPDRS: Unified Parkinson's disease rating scale.

Table 2:-Comparison of serum IGF-1 (Insulin like growth factor -1) and serum uric acid levels among different Parkinsonism groups and controls

\begin{tabular}{|c|c|c|c|c|c|c|c|c|}
\hline \multirow[t]{3}{*}{ Diagnosis } & \multicolumn{4}{|c|}{ Serum IGF-1 } & \multicolumn{4}{|c|}{ Serum Uric acid } \\
\hline & & & $\begin{array}{l}95 \% \mathrm{co} \\
\text { interva }\end{array}$ & $\begin{array}{l}\text { lence } \\
\text { mean }\end{array}$ & & & $\begin{array}{l}95 \% \mathrm{co} \\
\text { interva }\end{array}$ & $\begin{array}{l}\text { lence } \\
\text { mean }\end{array}$ \\
\hline & Mean & $\begin{array}{l}\text { Standard } \\
\text { deviation }\end{array}$ & $\begin{array}{l}\text { Lower } \\
\text { bound }\end{array}$ & $\begin{array}{l}\text { Upper } \\
\text { bound }\end{array}$ & Mean & $\begin{array}{l}\text { Standard } \\
\text { deviation }\end{array}$ & $\begin{array}{l}\text { Lower } \\
\text { bound }\end{array}$ & $\begin{array}{l}\text { Upper } \\
\text { bound }\end{array}$ \\
\hline
\end{tabular}




\begin{tabular}{|l|l|l|l|l|l|l|l|l|}
\hline IPD (n=66) & 368.57 & 131.49 & 336.50 & 400.64 & 4.87 & 2.56 & 0.55 & 12.99 \\
\hline $\begin{array}{l}\text { YOPD } \\
(\mathbf{n = 1 0})\end{array}$ & 347.47 & 122.08 & 260.14 & 434.80 & 5.83 & 1.91 & 4.31 & 10.23 \\
\hline MSA (n=7) & 277.73 & 138.72 & 149.44 & 406.02 & 5 & 3.72 & 1.47 & 12.45 \\
\hline PSP (n=14) & 364.26 & 124.04 & 292.63 & 435.88 & 6.62 & 3.85 & 1.36 & 17.64 \\
\hline $\begin{array}{l}\text { CBGD } \\
(\mathbf{n = 2})\end{array}$ & 366.26 & 84.45 & -392.50 & 1125.01 & 1.68 & 1.48 & 0.63 & 2.73 \\
\hline $\begin{array}{l}\text { Controls } \\
(\mathbf{n = 6 8})\end{array}$ & 279.53 & 116.7 & 251.49 & 307.56 & 7.45 & 2.58 & 3.63 & 15.27 \\
\hline
\end{tabular}

IPD: Idiopathic Parkinson's disease; YOPD: Young onset Parkinson disease; PSP: Progressive supranuclear palsy; MSA: Multi system atrophy; CBGD: Corticobasal ganglionic degeneration; NS: Not significant.

$* \mathrm{p}<0.05$ significant.

Table 3:-Comparison of Serum IGF-1 and Uric acid levels between total patients versus controls and PD versus PPS

\begin{tabular}{|l|c|c|c|l|l|l|}
\hline & $\begin{array}{c}\text { Total } \\
\text { patients(PD\& } \\
\text { PPS)(n=99) }\end{array}$ & Controls(n=68) & $\begin{array}{c}\text { Total } \\
\text { patients } \\
\text { versus } \\
\text { controls (p } \\
\text { value) }\end{array}$ & PD (n=76) & PPS(n=22) & p value \\
\hline $\begin{array}{l}\text { Serum } \\
\text { IGF-1 } \\
\text { levels } \\
\text { (ng/ml) }\end{array}$ & $358 \pm 129.01$ & $282.13 \pm 115.51$ & $<0.001^{*}$ & $364.02 \pm 129.62$ & $337.32 \pm 130.74$ & 0.39 \\
\hline $\begin{array}{l}\text { Serum } \\
\text { Uric acid } \\
\text { levels } \\
\text { (mg/dl) }\end{array}$ & $5.16 \pm 2.86$ & $7.45 \pm 2.58$ & $<0.001^{*}$ & $4.99 \pm 2.50$ & $5.72 \pm 3.94$ & 0.30 \\
\hline
\end{tabular}

PD: Parkinson's disease; PPS: Parkinson Plus Syndrome.

$\mathrm{P}<0.001 *$ Significant difference of serum IGF-1 and serum Uric acid levels between total patients (PD\&PPS) versus controls.

Table 4:-Correlation between Serum IGF-1 \& Serum Uric acid and clinical characteristics in PD patients.

\begin{tabular}{|l|c|c|}
\hline & Serum IGF-1 levels (ng/ml) & Serum Uric acid levels (mg/dl) \\
\hline Age of onset (Yr) & -0.094 & -0.206 \\
\hline Duration of illness (Yr) & 0.072 & 0.052 \\
\hline UPDRS Motor score & 0.002 & 0.050 \\
\hline UPDRS Total score & 0.032 & 0.060 \\
\hline H\& Y Stage & 0.068 & 0.032 \\
\hline
\end{tabular}

Pearson correlation coefficient was used to compare correlation between above mentioned parameters.

Correlation is significant at the 0.05 level (2-tailed).

*Significant inverse correlation of age of onset with Serum Uric acid levels was observed $(r=-0.206, p=0.04)$

\section{References:-}

1. de Lau LM, Breteler MM. Epidemiology of Parkinson's disease. Lancet Neurol.2006; 5(6):525-35.

2. Nussbaum RL, Ellis CE. Alzheimer's disease and Parkinson's disease. N Engl J Med. 2003; 348(14):1356-64.

3. Tanner CM, Goldman SM. Epidemiology of Parkinson's disease. Neurol Clin. 1996; 14(2):317-35.

4. Offen D, Shtaif B, Hadad D, Weizman A, Melamed E, Gil-Ad I. Protective effect of insulin-like-growth factor1 against dopamine-induced neurotoxicity in human and rodent neuronal cultures: possible implications for Parkinson's disease. Neurosci Lett. 2001; 316(3):129-32.

5. Godau J, Herfurth M, Kattner B, Gasser T, Berg D. Increased serum insulin-like growth factor 1 in early idiopathic Parkinson's disease. J Neurol Neurosurg Psych. 2010; 81(5):536-8.

6. Pellecchia MT, Santangelo G, Picillo M, Pivonello R, Longo K, Pivonello C, Vitale C, Amboni M, De Rosa A, Moccia M, Erro R, De Michele G, Santoro L, Colao A, Barone P. Insulin-like growth factor-1 predicts cognitive functions at 2-year follow-up in early, drug naïve Parkinson's disease. Eur J Neurol. 2014;21(5):8027. 
7. Godau J, Knauel K, Weber K, Brockmann K, Maetzler W, Binder G, Berg D. Serum insulin like growth factor 1 as possible marker for risk and early diagnosis of Parkinson disease. Arch Neurol. 2011;68(7):925-31.

8. Picillo M, Erro R, Santangelo G, Pivonello R, Longo K, Pivonello C, Vitale C, Amboni M, Moccia M, Colao A, Barone P, Pellecchia MT. Insulin-like growth factor-1 and progression of motor symptoms in early, drugnaïve Parkinson's disease. J Neurol. 2013; 260(7):1724-30.

9. Numao A, Suzuki K, Miyamoto M, Miyamoto T, Hirata K. Clinical correlates of serum insulin-like growth factor-1 in patients with Parkinson's disease, multiple system atrophy and progressive supranuclear palsy. Park Relat Disord. 2014; 20(2):212-6.

10. Mielke MM, Maetzler W. A "bird"s eye' view on the current status and potential benefits of blood biomarkers for Parkinson's disease. Biomark Med. 2014; 8(2): 225-7.

11. Golbe LI. Progressive supranuclear palsy. Semin Neurol. 2014; 34(2):151-9.

12. Bernhard FP, Heinzel S, Binder G, Weber K, Apel A, Roeben B, Deuschle C, Maechtel M, Heger T, Nussbaum S, Gasser T, Maetzler W, Berg D. Insulin-Like Growth Factor 1 (IGF-1) in Parkinson's Disease: Potential as Trait-, Progression- and Prediction Marker and Confounding Factors. PLoS One. 2016;11(3):e0150552.

13. Schaefer S, Vogt T, Nowak T, Kann PH. Pituitary function and the somatotrophic system in patients with idiopathic Parkinson's disease under chronic dopaminergic therapy. J Neuroendocrinol. 2008; 20(1):104-9.

14. Tuncel D, Inanc Tolun F, Toru I. Serum insulin-like growth factor-1 and nitric oxide levels in parkinson's disease. Mediators Inflamm. 2009; 2009:132464.

15. Davis JW, Grandinetti A, Waslien CI, Ross GW, White LR, Morens DM. Observations on serum uric acid levels and the risk of idiopathic Parkinson's disease. Am J Epidemiol. 1996; 144:480-4.

16. de Lau LM, Koudstaal PJ, Hofman A, Breteler MM. Serum uric acid levels and the risk of Parkinson's disease. Ann Neurol. 2005; 58:797-800.

17. Brody DM, Litvan I, Warner S, Riley DE, Hall DA, Kluger BM, et al. Relationship between uric acid levels and progressive supranuclear palsy. Mov Disord. 2016

18. Hughes AJ, Daniel SE, Kilford L, Lees AJ. Accuracy of clinical diagnosis of idiopathic Parkinson's disease: a clinico-pathological study of 100 cases. J Neurol Neurosurg Psychiatr. 1992; 55(3):181-4.

19. Litvan I, Agid Y, Calne D, Campbell G, Dubois B, Duvoisin RC, Goetz CG, Golbe LI, Grafman J, Growdon JH, Hallett M, Jankovic J, Quinn NP, Tolosa E, Zee DS. Clinical research criteria for the diagnosis of progressive supranuclear palsy (Steele-Richardson-Olszewski syndrome): report of the NINDS-SPSP international workshop. Neurology. 1996; 47(1):1-9.

20. Gilman, S., Wenning, G. K., Low, P. A., Brooks, D. J., Mathias, C. J., Trojanowski, J. Q., ... Vidailhet, M. (2008). Second consensus statement on the diagnosis of multiple system atrophy. Neurology, 71(9), 670-6.

21. Armstrong MJ, Litvan I, Lang AE, Bak TH, Bhatia KP, Borroni B, Boxer AL, Dickson DW, Grossman M, Hallett M, Josephs KA, Kertesz A, Lee SE, Miller BL, Reich SG, Riley DE, Tolosa E, Tröster AI, Vidailhet M, Weiner WJ. Criteria for the diagnosis of corticobasal degeneration. Neurology. 2013; 80(5):496-503.

22. Fahn S, Elton R, Members of the UPDRS Development Committee. In: Fahn S, Marsden CD, Calne DB, Goldstein M, eds. Recent Developments in Parkinson's Disease, Vol 2. Florham Park, NJ. Macmillan Health Care Information 1987, 153-163, 293-304.

23. Hoehn MM, Yahr MD. Parkinsonism: onset, progression and mortality. Neurology 1967; 17(5):427-42.

24. Li DH, He YC, Quinn TJ, Liu J. Serum Insulin-Like Growth Factor-1 in Patients with De Novo, Drug Naïve Parkinson's Disease: A Meta-Analysis. PLoS One. 2015; 10(12):e0144755. 